\title{
Towards a biblical model of Pentecostal prophetic preaching
}

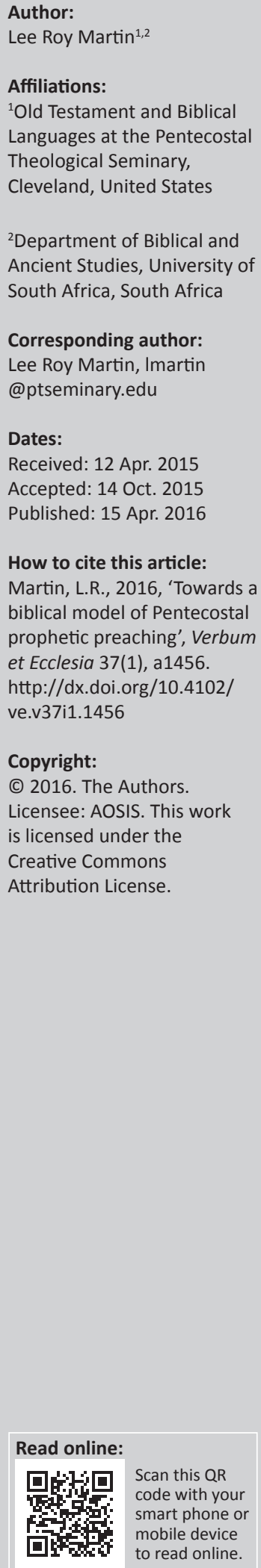

The growth and diversity of Pentecostalism has produced questions regarding appropriate methods for Pentecostal preaching. Increasing educational levels among Pentecostal pastors have caused many of them to move to more mainline Protestant approaches to preaching. This article, although allowing for diverse models of preaching, calls for an appreciation of Pentecostal approaches to preaching and suggests the appropriation of a biblical model of prophetic preaching. A paradigm for prophetic preaching emerges through an examination of biblical prophetic ministry as it intersects with Pentecostal practice. It is suggested that a contemporary model of Pentecostal prophetic preaching can be informed by the biblical models.

Intradisciplinary and/or interdisciplinary implications: This study suggests intersections between biblical studies, historical theology, homiletics, and contemporary culture. It is argued that Pentecostal preaching should be based upon biblical models, while taking into consideration historical and cultural contexts. This work integrates the disciplines of biblical studies, practical theology, homiletics, and Pentecostal worship studies. Results from the biblical study of the prophets suggest that contemporary Pentecostal homiletical theory should entertain a model of prophetic preaching that emulates the goals and methods of the biblical prophets. The Pentecostal preaching tradition continues to offer valuable insights into effective preaching models; therefore, Pentecostal homiletics should not be based entirely upon western Protestant models of preaching.

\section{Introduction}

The purpose of this article is to develop a contemporary paradigm of Pentecostal prophetic preaching. Historically, the Pentecostal movement has included a variety of preaching models, and prophetic preaching is only one out of many. Therefore, although this article isolates prophetic preaching as a subject of investigation, it is acknowledged that many other approaches to preaching are legitimate (and even necessary) for the Pentecostal church. Prophetic preaching, as I understand it, does not consist in foretelling the future or preaching about the last days. Furthermore, as Goldingay posits, it must not be reduced to social criticism (Goldingay 2001:34-36). For the purpose of this article prophetic preaching is preaching that finds its model in the proclamation of the biblical prophets. Therefore, my discussion will unfold in two steps. Firstly, I will develop a broad working definition of biblical prophecy. Secondly, I will suggest a number of key correspondences between the biblical model of prophecy and Pentecostal preaching.

\section{Defining prophecy}

The word 'prophecy' is difficult to define precisely (Goldingay 2001:27). It displays a wide range of meanings throughout Scripture, in history, and in contemporary usage; therefore, it is impossible to formulate a single definition that is appropriate to every context. In the Bible, prophecy can refer to the books of the Bible (2 Pt 1:19-21; Rv 22:18-19), glossolalia (Ac 2:16-18), songs of praise

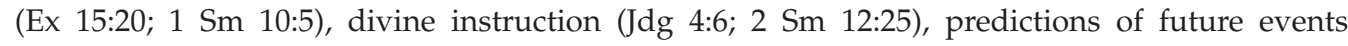
(1 Ki 16:12; 20:13; 22:17; Ac 21:10-11), and performance on musical instruments (1 Chr 25:1). Prophecy can even be expressed through symbolic actions like tearing a garment (1 Ki 11:29-31), wearing an animal mask (1 Ki 22:11-12), marrying a prostitute (Hs 1:2), giving symbolic names to children (Hs 1:3-9), walking naked (Is 20:1-3), wearing a yoke (Jr 27:1-12), cooking over dried dung (Ezk 4:9-17), and tying one's hands and feet (Ac 21:10-11).

The ministries of biblical prophets varied greatly. Prophets like Moses, Elijah, and Elisha were known for working miracles, signs, and wonders, whereas other prophets were not. Moses,

Note: Lee Roy Martin is a Research Fellow at the University of South Africa, Department of Biblical and Ancient Studies. 
Samuel, and Deborah were recognised as prominent leaders, but most of the prophets held no official position of power. Prophets like Isaiah, Jeremiah, Ezekiel, and Amos exercised a public preaching ministry; whereas others, such as Elijah, Elisha, Nathan, and Huldah ministered mostly one-on-one. Isaiah and Jeremiah served as prophets for virtually their entire lives, but other prophets like Amos, Haggai, and Malachi apparently prophesied for short periods of time.

The Didache: The Teaching of the Twelve Apostles, one of the earliest Christian documents, shows that itinerate prophets were part of the experience of the second-century church (Milavec 2004), and the continuation of prophetic gifts has been traced throughout church history by numerous scholars (e.g. Hvidt 2007; Lum 2010; Robeck 1992). The exercise of prophecy among classical Pentecostals and Charismatics has been modelled largely after Paul's instructions to the church at Corinth (Ahn 2013; Fee 1994; Quayesi-Amakye 2011). However, a number of new and diverse models of prophetic ministry have arisen in recent years, all of which demand the Church's discernment (Dodson 2011; Maimela 1990; Sandford 2009).

Despite the uniqueness of each biblical prophet and the many ways that prophecy is manifested in Scripture and in church history, scholars continue to search for a core definition of prophecy by elaborating on the common characteristics of biblical (and post-biblical) prophecy. My first inclination was to develop from the biblical prophets a definition of prophetic ministry; but, in light of the fact that much work on the prophets has already been done, I chose instead to work from pre-existing definitions that have been developed by other scholars. It is far beyond the scope of this article to examine the entire voluminous corpus of scholarship on prophecy; therefore, I will summarise only four writers. These four are chosen for two reasons. Firstly, they most closely represent my own view of biblical prophecy. Secondly, they have defined prophecy in ways that intersect helpfully with Pentecostal preaching. These four scholars are Abraham J. Heschel, Walter Brueggemann, John Goldingay, and Rickie D. Moore. Heschel, Brueggemann, and Goldingay are renowned Old Testament scholars, and Moore is a highly respected Old Testament scholar in the Pentecostal movement.

\section{Abraham J. Heschel}

It is my view that no one comes closer to describing the heart of the prophetic experience than Heschel (1962). He argues that the prophets are best understood as bearers of the pathos of God. Heschel (1962) writes:

... the fundamental experience of the prophet is a fellowship with the feelings of God, a sympathy with the divine pathos, a communion with the divine consciousness which comes about through the prophet's reflection of, or participation in, the divine pathos ... The prophet hears God's voice and feels His heart. He tries to impart the pathos of the message together with its logos. As an imparter his soul overflows, speaking as he does out of the fullness of his sympathy. (pp. I, 26)
According to Heschel (1962), the prophet is not a mere passive recipient of revelation, who then preaches a rote message to the listeners. Instead:

The prophet claims to be far more than a messenger. He is a person who stands in the presence of God ... who is a participant, as it were, in the council of God. (pp. I, 21)

\section{Walter Brueggemann}

Just as clearly as Heschel describes the experience and consciousness of the prophets, Walter Brueggemann sets forth their essential goal and message. Brueggemann resists the common reductionistic stereotypes of the prophets as either predictors of the future (a Fundamentalist approach) or social reformers (a Liberal approach). He argues that even though the prophets often foretell future events, 'they are concerned about the future as it impinges upon the present' (Brueggemann 1978:12). Furthermore, he acknowledges that prophecy demonstrates deep concern for society, but it 'cannot be reduced to righteous indignation' (Brueggemann 1978:13). Therefore, Brueggemann insists, 'The task of prophetic ministry is to nurture, nourish, and evoke a consciousness and perception alternative to the consciousness and perception of the dominant culture around us' (Brueggemann 1978:13, emphasis original). This work is accomplished through two basic forms of the prophetic message: prophetic 'of the 'dominant consciousness' and prophetic 'of the community of faith. The prophet, therefore, encourages the community both to envision and to move towards an alternative world of justice and righteousness in with God is the central and determining factor. Brueggemann concludes that all acts of ministry (not just preaching) should be 'seen as elements of the one prophetic ministry of formation and reformation of alternative community' (Brueggemann 1978:14).

\section{John Goldingay}

John Goldingay argues that prophetic ministry is not limited to the biblical period but continues in the church today. $\mathrm{He}$ points to Joel 2:28-29 as evidence that the exercise of prophecy will be a feature of the full life that God intends for the chosen people of God' (Goldingay 2001:28; cf. Hvidt 2007:4). Goldingay outlines the ministry of the prophet in nine points. Firstly, he points out that 'A Prophet Shares God's Nightmares and Dreams' (Goldingay 2001:28-31). That is, the message of the prophet is not generated by the prophet's political observations or religious acumen, but it is revealed to the prophet from God.

Secondly, in positing that 'A Prophet Speaks like a Poet and Behaves like an Actor' (Goldingay 2001:31-32), Goldingay highlights the imaginative methods of the prophets. Prophetic messages are couched in the symbolic language of imagery and figures of speech. In addition to metaphorical language, they often utilised symbolic actions that were sometimes shocking.

Thirdly, 'A Prophet Confronts the Confident with Rebuke and the Downcast with Hope' (Goldingay 2001:33-34). With this 
statement, Goldingay echoes Brueggemann's terminology of prophetic 'criticizing' and prophetic 'energizing'.

Fourthly, Goldingay declares that 'A Prophet's Task Is Mostly to Speak to the People of God' (Goldingay 2001:34-36). Popular (and sometimes scholarly) perspectives on the prophets have mistakenly viewed prophecy as a critique of secular culture; however, the biblical text shows that the prophets' primary audience was the people of God.

Fifthly, 'A Prophet Is Someone Independent of the Institutional Pressures of Church and State' (Goldingay 2001:36-39), which means that the prophet was not beholden to kings, priests, and nobility. The kings apparently employed advisors who were called 'court prophets', but prophets like Elijah, Elisha, Amos, and Jeremiah were 'not on the payroll' (Goldingay 2001:37). Therefore, they had the freedom to confront the authorities.

Sixthly, because she or he embodies the authority of the almighty God, 'A Prophet Is a Scary Person Who Mediates the Activity of a Scary God'. God's majesty, awesomeness, and power are projected through the life and ministry of the prophet.

Seventhly, 'A Prophet Intercedes with Boldness and Praises with Freedom' (Goldingay 2001:41-42). The prophet mediates between heaven and earth; and, sometimes, that role requires the prophet to intercede on behalf of the people of God.

Eighthly, 'A Prophet Ministers in a Way that Reflects His or Her Personality and Time' (Goldingay 2001:42-44). Although the prophets speak words that are given to them by God, their words take on the personality and character of the individual prophet and/or the character of the prophetic community to which the prophet belongs.

Ninthly, and finally, 'A Prophet is Likely to Fail' (Goldingay 2001:44-46). When Goldingay speaks of failure, he means two things. Firstly, the prophet is fallible and liable to make mistakes. Secondly, the message of the prophet often goes largely unheeded when it is spoken.

\section{Rickie D. Moore}

According to Moore, the Old Testament prophet fulfils the complicated and connected roles of 'messenger', 'minstrel', 'madman', 'martyr', and 'mentor' (Moore 2004:16-29, 2007:155-73). The prophet's primary role as messenger can be discerned from the Hebrew word for prophet (nabi), which, Moore argues, can mean both 'one who is called' and 'one who calls' (that is, speaks forth God's message). The role of messenger is further illuminated by the common prophetic use of the phrase 'thus saith the Lord', which scholars call the 'Messenger Formula' (Moore 2004:17-19).

If the prophet is a messenger, then the prophet's message can be described by three terms: 'word of the Lord', 'vision', and 'burden'. According to Moore, the word of the Lord (davar Yhwh) is more than 'information', but is an experience of 'transformation' that comes powerfully to the prophet as a divine encounter (Moore 2004:18). The word 'vision' (chazon) suggests that 'all of the discrete revelations that came to the prophet ... come together to generate, to comprise, and to reflect an overarching perspective, a kind of God-induced view of reality or world view' (Moore 2004:19). The third term, 'burden' (massa), is 'a heaviness that is carried before (and sometimes after) it becomes a message that is delivered' (Moore 2004:20). Through the process of prophetic revelation, God is transforming the prophet, infusing the prophet with God's passions.

Moore argues that the prophet's communication of God's passions is cast appropriately in poetic forms. Therefore, the prophet can be called a 'minstrel' (Moore 2004:21-23). The creative, emotive, and illusive language of poetry is perfectly fitted for expressing the passionate message of the prophets.

The strange speech and abnormal behaviour of the prophets leads to the charge that the prophet is a 'madman' (Moore 2004:24-26). Moore cites biblical texts like Hosea 9:7, 'the prophet is a fool; the man of the Spirit is mad', to show that the accusation of madness is not uncommon. The madness of the prophets originates in their possession by the Spirit of God, which lifts them into God's presence, into God's sanity. God's sanity, however, is insanity to the prophet's hearers.

The uncompromising message of the prophet often results in persecution, and even execution, by the audience. Thus, Moore declares the prophet to be a 'martyr'. The prophet, however, is a martyr in still another sense. The prophet's dramatic encounter with God is an apocalyptic event that effectively ends the prophet's life as it was before the encounter. No one can see God and live; therefore, the prophets die because they witness God (Moore 2004:27-29).

In assigning to the prophet the role of mentor, Moore argues that the popular characterisation of the prophet as a lonely and isolated figure who has little to no contact with society results from a misunderstanding of the biblical text (Moore 2007:156). He finds evidence from the biblical portrayals of Moses, Elijah, and Isaiah that the prophets were surrounded by colleagues and followers who supported the prophetic ministry and who participated in carrying on the prophetic tradition.

\section{Prophetic preaching}

Among the biblical prophets, those whom we call the Latter Prophets (Isaiah-Malachi) are the most notable as preachers. I use the word 'preacher' in its common, straightforward sense. A preacher is one who proclaims a sermon to a group of listeners (cf. OED, s.v. 'preacher'). However, it is clear from biblical and historical precedents that the concept of prophecy is much broader than preaching alone. Therefore, the Evangelical cessationist view that reduces prophecy to preaching has no warrant in the biblical text (cf. Ahn 2001:77-86; Chan 2000:36-37; Sheppard 2001:64). Even though 
preaching and prophecy overlap at certain points, not all prophecy is preaching, and not all preaching is prophecy. The purpose of this article is to look at those places where prophecy and preaching overlap and to develop from those intersections a theology of Pentecostal prophetic preaching.

\section{The prophetic calling}

The biblical prophets experienced dramatic encounters with God that 'radically transformed' them and initiated their entrance into prophetic ministry (Heschel 1962:I, 28). These encounters are reported in the form of call narratives that bear similarities to the testimonies of many Pentecostal preachers. Moses, Isaiah, Jeremiah, and Ezekiel are examples of biblical prophets who experienced theophanic callings.

Powerful call narratives are not limited to the Old Testament. The baptism of Jesus bears similarities to the pattern found in the earlier prophetic encounters (Mt 3:13-17). Furthermore, the calling of the apostle Paul is equal in splendour to that of Moses, Isaiah or Ezekiel (Ac 9:1-20).

The prophetic calling fills the preacher with a compelling urge to proclaim the divine word (Black 1983:17). The apostle Paul declares, 'Although I preach the gospel, I have nothing to glory of; for necessity is laid upon me. Yes, woe is unto me, if I do not preach the gospel' (1 Cor 9:16). When Peter and John were ordered by the Jewish authorities to cease preaching about Jesus, they replied, 'We cannot stop speaking what we have seen and heard' (Ac 4:20). The prophet Amos writes, 'The lion has roared, who will not fear? The Lord God has spoken, who can refuse to prophesy?' (Am 3:8). Early Pentecostal leader, A.J. Tomlinson, wrote in his diary of a similar compulsion to preach: 'The Holy Ghost put a great yearning in our hearts to go and teach and preach the gospel that souls might be saved' (Tomlinson 2012:18).

Not unlike the biblical prophets, many Pentecostal preachers claim to have received their callings through remarkable encounters with God. Recounting her experience, Cora A. Nelson (1914), writes:

This was in 1904. I began to fast and pray for more power. On the fourth day of fasting and prayer at 9 o'clock in the morning, Aug. 27, Jesus appeared to me ... He said to me, I have chosen you to preach my Gospel. (p. 7)

For Pentecostals, the call narrative often includes an element not found in other traditions - the experience of Spirit baptism. Pentecostals believe that Spirit baptism is the quintessential prophetic encounter that transforms the believer, resulting in a reordering of all of life in terms of a derivative apocalyptic spirituality (Land 2010:50-63). On the day of the Pentecost, Peter connected the reception of the Spirit with the continuation of prophecy. After being filled with the Spirit, Peter stands and says:

But this is that which was spoken by the prophet Joel: And it shall come to pass in the last days, says God, I will pour out my Spirit upon all flesh, and your sons and your daughters shall prophesy, and your young men shall see visions, and your old men shall dream dreams; and on my servants and on my maid servants I will pour out my Spirit in those days, and they shall prophesy. (Ac 2:16-18)

The prophetic preacher's experience of divine calling serves several important functions. Firstly, for the prophet, the call is the end of one life and the beginning of another; it is the initiation to ministry. The call experience is the necessary divine ordination and authorisation for ministry. Secondly, the testimony of call is a sign to the community. The fact that Scripture records many prophetic call narratives suggests their importance for the faith community. Furthermore, those who were called would sometimes use their calling as a way of establishing their credentials. When Moses arrived in Egypt, he immediately reported to the Israelites his experience at the burning bush. One of the most notable elements in the narrative of the Acts of the Apostles is the repetition of Paul's testimony regarding his call on the road to Damascus. Not only was the experience valuable for Paul, but it carried authority in the Christian community and beyond. Thirdly, a clear sense of calling provides stability and assurance to the prophet when challenges arise. Just as Jeremiah faced opposition, so will all prophetic preachers (Black 1983:24). Fourthly, the divine call is a transformative, apocalyptic encounter that effectively destroys and then rebuilds the prophet (cf. Is 6:5, 'Woe is me, for I am undone!'). As Heschel puts it, 'The prophets must have been shattered by some cataclysmic experience in order to be able to shatter others' (Heschel 1962:I, 12). Fifthly, the divine encounter makes the prophet a fertile field in which the germination of prophetic messages can take root and grow. The prophet's call is only the initial prophetic experience, but it opens the prophet to the possibility of further revelations and messages.

The Pentecostal approach to calling is not without its problems. The spiritual experiences that are claimed by some preachers can easily lead to elitism in which those who have special 'callings' are exalted above the laity and even above other ministers who have not enjoyed the same experiences. It is vital for the health and mission of the church that spiritual caste systems be rejected as unbiblical. Paul's letters to the Corinthians - especially his theology of the Church as Christ's body - is a helpful corrective to those who would claim higher spiritual status based upon their gifts and callings.

\section{The prophetic message}

\section{The prophetic message originates in God, not in the prophet}

As an indication that they were messengers of God and that the message did not originate with them, the prophets often prefaced their proclamations with the Messenger Formula: 'Thus says the Lord ...' (koh amar Yhwh). At other times they would conclude their message with the words, '... declares the Lord' (neum Yhwh). More than 240 times in the Old Testament, the prophetic message is characterised as 'the word of the Lord', a designation which strengthens the prophetic claim to inspiration. 
Prophetic revelation is also called a 'vision' (chazon), as we find in Isaiah 1:1, "The vision of Isaiah the son of Amoz, which he saw concerning Judah and Jerusalem ...' Prophetic vision is the transformation of the prophet's view of the world. Instead of seeing the world from the human perspective, the prophet is enabled to see the world from God's perspective (Moore 2004:19). Heschel argues, therefore, that 'prophecy consists in the inspired communication of divine attitudes to the prophetic consciousness' (Heschel 1962:II, 223).

In Scripture, anyone who claimed to be a prophet but preached something other than the Lord's message came under God's judgement. In Jeremiah's day, the Lord warned the people about deceitful prophets. The Lord said:

Do not listen to the words of the prophets who are prophesying to you. They are leading you into futility. They speak a vision out of their own imagination, not from the mouth of the Lord. (Jr 23:16)

In pursuit of the prophetic ideal, Pentecostal preachers have preferred to call their preaching a 'message' rather than a 'sermon'. Furthermore, they have traditionally relied upon the Holy Spirit to supply them with the inspired message appropriate to each unique occasion. The following entry in A.J. Tomlinson's (2012) diary illustrates the Pentecostal practice:

I had been waiting on God all morning for a message for the meeting. Could get nothing. Meeting commenced. I felt all broken up ... and knelt in prayer ... God gave a message from the life of Joseph. The Holy Ghost and fire fell upon us and we had an old fashioned Pentecost. (p. 13)

Cora A. Nelson, in her narrative mentioned above, goes on to testify that Jesus not only called her to preach, but he also pointed her to Colossians 3 as the text for her first message. She went to church that night; and the pastor, without knowing her story, invited her to preach. She stood up and preached from Colossians 3 as the Lord had instructed her (Nelson 1914:7).

Pentecostal preachers continue to use prophetic terminology when describing their ministry. For example, as I was writing this article, I was pleased to hear Dr. Welton Wriston (2015) introduce his chapel sermon with the following words:

I have a message for you this morning that the Lord has laid on my heart for several months ... You know, as a person who is called to preach, ... You know when God deposits something in your spirit, and you know when God will not let you get away from it. (n.p.)

Wriston's personal disclosure reflects his thoroughgoing Pentecostal traditioning. For a prophetic preacher, the sermon must be a message that God has 'laid on' the heart, a message that the prophet cannot 'get away from'.

Although both Tomlinson and Wriston stick with the term 'message', Pentecostals also speak of the prophetic word as a 'burden', which is still another Old Testament prophetic label. The prophets Isaiah, Jeremiah, Ezekiel, Nahum, Zechariah, and Malachi all describe their messages as a 'burden' (massa). Although some translations understand the word to mean 'oracle', the Hebrew comes from the verb 'to lift or carry' (nasa), and it is used in various places with the literal meaning of 'a burden or load that is carried by a person or animal'. For example, the priestly sons of Kohath are assigned the 'burden' of transporting the tabernacle ( $\mathrm{Nm} \mathrm{4:15).} \mathrm{All} \mathrm{of} \mathrm{this} \mathrm{suggests} \mathrm{that} \mathrm{the} \mathrm{prophetic} \mathrm{burden} \mathrm{is} \mathrm{a}$ responsibility that is to be carried by the prophet until it is delivered to the intended audience (Moore 2004:20).

Pentecostal preachers, therefore, believe themselves to be proclaiming an inspired message, given for a specific time and place, a word from the Lord. They assert that while study is necessary in building an effective sermon and knowledge of the times and context is essential for making the sermon relevant, neither study nor insight can give birth to a prophetic message (Bishop 1983:27).

This claim of prophetic inspiration, however, opens the door to a number of abusive practices. The preacher who claims this kind of inspiration may be tempted to assert infallibility and unquestioned authority. For this reason, a strong ecclesiology is required, an ecclesiology which insists upon accountability to the community of faith and which includes a system for ensuring the theological orthodoxy of the ministers. No preacher should be allowed to operate outside the authority of the Church as a whole.

\section{The prophetic message is a biblical message}

The fresh messages of the biblical prophets were grounded in the Torah of Moses; and, in corresponding fashion, the Pentecostal prophetic message must be rooted soundly in Scripture. Prophetic preaching is scriptural preaching, and it should focus on the biblical text (Brueggemann 2012:1-2). Brueggemann contends that prophecy, though creative and imaginative, is not a 'personal invention. Rather, these poets probe and mine the tradition in ways that cause the old tradition to articulate a newness' (Brueggemann 1986:2). Similarly, John Goldingay argues that prophetic messages are creative restatements of Israel's earlier story (Goldingay 2001:31). Therefore, each prophetic message can be new, unique, and contextual, while, at the same time, remaining faithful to the scriptural tradition.

The prophets reimagined the Torah for their context, and today's prophetic preacher must do the same. All faithful preaching is the proclamation God's Word, but prophetic preaching is God's Word for the present context - given by the Holy Spirit for a particular moment and for a particular audience. Often, the new message is compared to the old by way of analogy, as in Hebrews 3, where the writer of Hebrews links the exodus and Moses to the situation of the early Hebrew congregation. In light of the story of the exodus, the hearers of the book of Hebrews are admonished to receive God's Word by faith and to continue forward in their journey to the Promised Land. 


\section{The prophetic message situates God at the centre}

Not only can prophetic preaching be described in terms of its origin in God and its focus on Scripture, it can also be described in terms of its content. Much of today's preaching consists of reflection on current events, self-help advice, and inspirational anecdotes that paint the Christian faith as utilitarian and consumer oriented. Prophetic preaching, however, deals with deeper and more urgent matters. Brueggemann writes, 'At the centre of prophetic imagination is $\mathrm{YHWH}^{\prime}$ as an active agent in the world (Brueggemann 2012:442). Consequently, he (Brueggemann 2012) defines prophetic preaching as:

an attempt to imagine the world as though $\mathrm{YHWH}$ - the creator of the world, the deliverer of Israel, the Father of our Lord Jesus Christ, whom we Christians come to name as Father, Son, and Holy Spirit - were a real character and an effective agent in the world. (p. 2)

Brueggemann's thesis that God is 'a real character and an effective agent in the world' is easily confessed by Pentecostals and might even be considered to be the heart of Pentecostal epistemology and the core message of Pentecostal preaching.

God's personal involvement in the life of the world and in the life of God's people is the message of the Torah. The world is God's world, created by God and for God; and Israel is God's people, also created by God for God. The Torah stands in stark contrast to the world's 'dominant narrative' and contends that the 'dominant narrative of the world is not adequate and so cannot be true' because it omits the character of YHWH, without which there is no authentic life or viable hope (Brueggemann 2012:12). The Torah is a given and not negotiable among new generations. The Torah requires Israel to be a new kind of community, an 'alternative community' (Brueggemann 1978:14). The alternative community created through the Mosaic covenant is a community of justice and righteousness in which God is the central and determining factor.

\section{The prophetic message may point to judgement or to salvation}

The prophetic work of revisioning the Torah is accomplished through two basic forms of the prophetic message: prophetic 'of the 'dominant consciousness' and prophetic 'of the community of faith (Brueggemann 1978:14). Prophetic criticising is the confronting of God's people with their violations of Torah. As long as Israel adhered to the Torah and the Mosaic covenant, they enjoyed the blessings of God and prophets were not required. However, the criticising message of the Old Testament prophets was necessary because Israel departed from the Torah's representation of God and from Israel's commitment to the Mosaic covenant with its stipulations and consequences.

Similarly, all Christians confess their belief in the Bible and their commitment to the God of the Bible, but their lives betray their unbiblical allegiances and their acquiescence to the 'dominant narrative' of the world. Brueggemann, therefore, sees prophetic preaching as a confronting of the Church's hypocrisy and an attempt to bring the Church back to the 'alternative consciousness' that is found in Scripture (Brueggemann 1978:13). He writes:

Prophetic proclamation is the staging and performance of a contest between two narrative accounts of the world and an effort to show that the YHWH account of reality is more adequate and finally more reliable than the dominant narrative account that is cast among us as though it were true and beyond critique. (p. 3)

The fact that prophetic preaching contradicts the dominant narrative has been recognised by Pentecostal preachers from the beginning of the movement. Early Pentecostals did not participate in the American Fundamentalist-Modernist Controversy, but instead imagined an entirely different world view. That is, they did not adopt higher criticism (a la Charles Briggs), but neither did they participate in the Fundamentalist response (a la J.G. Machen). Brueggemann's perspective is a welcome reminder to Pentecostals today, however, because many Pentecostals are now being seduced by what Brueggemann calls 'the dominant narrative' and could benefit from prophetic criticising.

Prophetic criticising may go beyond a call to return to the Torah and may consist of a word of inevitable judgement, punishment, and loss. Prophetic preaching, therefore, includes the process of lamenting and grieving over loss until the reality of loss can be faced and the old world can be relinquished. Brueggemann claims that American society either stubbornly denies the loss or has succumbed to despair, and prophetic preaching must show the pathway through grief to new possibility. The value and necessity of lament has been a significant feature of Pentecostal practice. Although the prosperity preachers make a lot of noise, they do not represent the heart of the Pentecostal tradition. Larry McQueen has documented the important role of lament in Pentecostalism (McQueen 2009; cf. Melton 2011).

As soon as judgement and loss were assured by the exile, the prophets moved from criticising to energising. Prophetic energising is the proclamation of hope where there seems to be no hope. In moving from judgement to salvation, the prophets no longer looked to Sinai as their primary source for prophetic imagination. Instead, they utilised the Genesis tradition with its themes of creation and promise. The stories of Sarah and other barren women who were enabled to bear children were particularly useful in this regard. One key text is Genesis 18:13-14, where the Lord asks, 'Is anything too wonderful for the Lord?' The word 'wonderful' can be translated 'impossible', and Brueggemann lays out a number of prophetic texts that turn on the theme of God's doing of 'wonders' or 'that which is impossible' (Brueggemann 2012:101-128).

This newness is apparent in the New Testament story of the life, parables, and resurrection of Jesus. The prophetic preacher must be able to recognise when and how to transition from addressing judgement and loss to speaking 
about God's resolve to do something new. Heschel (1962) writes:

The words of the prophets are stern, sour, stinging. But behind this austerity is love and compassion ... Almost every prophet brings consolation, promise, and the hope of reconciliation along with censure and castigation. He begins with as message of doom; he concludes with a message of hope. (pp. I, 12)

The prophet proclaims 'words of new possibility' in the face of life depleting impossibilities (Brueggemann 2012:128). Brueggemann (2012) argues that:

prophetic preaching is the enactment of hope in contexts of loss and grief. It is the declaration that God can enact a novum in our very midst, even when we judge that to be impossible. (p. 110)

The two-fold message of judgement and hope resonates with Pentecostal theology and recalls John Wesley's frequent references to preaching as both wounding and healing (1909: IV, 484, 499; VI, 165; VII, 248). As a Pentecostal, I find satisfaction in Brueggemann's structuring of prophecy in and around these dual modes of prophetic proclamation (cf. Goldingay 2001:33-34). The heart of the Pentecostal message is the five-fold Gospel (the proclamation of Jesus as Saviour, Sanctifier, Spirit-baptiser, Healer, and Soon Coming King [Dayton 1987:20; Faupel 1996:39; Land 2010:38, 39, 90]), and embedded throughout this gospel is the challenge to relinquish that which is old and to receive that which is new. Prophetic preaching does not limit future possibilities on the basis of how things appear now.

\section{Prophetic passion}

Prophetic preaching conveys more than information. As Heschel states, 'The task of the prophet is to convey the word of God. Yet the word is aglow with the pathos' (Heschel 1962:26). The Old Testament prophet embodies the 'pathos' of God, experiencing the passions of God and transmitting those divine passions to the hearers.

Rickie Moore argues that the prophetic passion has its genesis in the 'radical theophanic encounter' of the call experience (Moore 2004:27). The prophet's vision of God produces a transformation of the affections in which God's passions are infused into the prophet. The passions of God are further communicated to the prophet through ongoing reception of the 'word of the Lord', which, according to Moore, 'is no mere datum of information. It is more like a quantum of transformation' that happens to the prophet (Moore 2004:18, emphasis original). Therefore, the prophetic preacher is one whose affections have been radically altered by means of divine encounter.

Therefore, bearing the pathos of God, 'The prophet ... feels fiercely' (Heschel 1962:5). At first, the reception of God's Word may produce a sense of joy and wonder. Reflecting on his experience, Jeremiah writes:

Your words were found, and I ate them; and your word was for me the joy and rejoicing of my heart: for I am called by your name, O Lord God of hosts. (Jr 15:16)
Soon, however, the weight of the prophetic burden brings pain instead of joy, and Jeremiah complains:

My heart is broken within me, all my bones tremble; I am like a drunk, like one overcome by wine, because of the Lord, and because of his holy words. (Jr 23:9)

Prophetic preaching is the communication of both the joy and pain of God's pathos.

The prophet experiences pathos from two directions. As the messenger of God, the prophet is filled with God's passions; but, as a member of the community, the prophet suffers along with everyone else. Heschel writes, 'In the presence of God [the prophet] takes the part of the people. In the presence of the people [the prophet] takes the part of God' (Heschel 1962:24). The best prophetic preaching, therefore, is the communication of the pathos of God by a prophet who speaks from a position of solidarity with the people of God.

The nature and character of the prophetic message requires passionate language. When engaged in prophetic criticising, 'The prophet's words are outbursts of violent emotions' in reaction to the evil and complacency of society (Heschel 1962:4). Even when engaged in prophetic energising, powerful emotive expression is called for. Prophetic preaching challenges assumptions, interrupts apathetic slumber, exposes sin and hypocrisy, and requires repentance. Dispassionate modes of discourse cannot accomplish the goals of prophetic preaching. Therefore, a prophetic message will be delivered with passion and with an abundance of affective language.

The affective approach, passionate delivery, and unconventional methods have caused the prophet to be 'as a madman' by contemporaries (Heschel 1962:18; Moore 2004:24-26). Pentecostal prophetic preachers have been abused in similar fashion and caricatured as fanatics. It should be conceded that the criticism of Pentecostal preaching as 'emotionalism' is not entirely without foundation. On the whole, Pentecostalism has resisted education, and Pentecostal preachers have often relied more upon sound than substance. Although many contemporary Pentecostal preachers have adopted a more refined style of delivery, it is true historically that:

in its sermons, there has been a heavy emphasis on emotional involvement. In this sense, Pentecostal preaching may sometimes be defined as the powerful and passionate proclamation of God's good news. (Leoh 2006:45)

The goal of prophetic passion is not to entertain or attract attention to the prophet but to transform the affections of the hearers in the same way that the prophet has been transformed. Of course, the prophetic message must include informational content and rational argument, but the message may serve not so much to inform as to transform. That is, a prominent role of the prophet is to reorient and shape the affections of the hearers so that the affections are formed after God's affections. The objective is the full restoration of the covenant relationship between God and the people of God. 


\section{Prophetic artistry}

Scholars have long observed that the biblical prophets stage their speech in poetic forms. The passion of prophetic preaching cannot be expressed in flat prose and precise logic; it requires a creative and artistic mode of discourse. Prophetic messages are couched in the symbolic language of imagery and figures of speech. In addition to metaphorical language, they often utilise symbolic actions that are sometimes shocking. Fritz Medicus writes, 'God needs prophets in order to make himself known, and all prophets are necessarily artistic. What a prophet has to say can never be said in prose' (Medicus 1917:14). Similarly, Walter Brueggemann finds in Jeremiah's poetic style 'an invitation to seek for language that is passionate, dangerous, and imaginative enough to make available the passion, danger, and freedom of God' (Brueggemann 1986:15). Rickie Moore agrees that the creative, emotive, and illusive language of poetry is perfectly fitted for expressing the passionate message of the prophets (Moore 2004:21-23).

In light of the biblical models of prophetic speech, I would plead for a reappropriation of the artistic, emotive, and creative character of early Pentecostal preaching in the place of the more recent turn towards the rationalistic, formal, and frigid approaches. Cleophus J. LaRue (2011), Professor of Homiletics at Princeton Theological Seminary, offers the following critique of American Protestant preaching:

on the whole it is too flat, too horizontal, too colourless - in a word, unimaginative. It too often lacks sparkle, intrigue, provocative thought, and mental images that help us to see and to say the Word in new ways. (p. 71)

LaRue explains that this complaint is not true of African American preaching, and I would argue that it has not been true of Pentecostal prophetic preaching. Although both African American preaching and Pentecostal preaching are quite varied and diverse, they share many common characteristics that place them in sharp contrast to other preaching traditions. Among these common traits are the dynamic, creative, and artistic approaches to preaching that are described in LaRue's work.

Pentecostals must not allow themselves to be robbed of their valuable artistic models by misguided (albeit well-meaning) critics. The adoption of preaching models that are not compatible with Pentecostal theology and are not conducive to Pentecostal spiritual formation will have far-reaching negative consequences. It should be pointed out, however, that skilful artistic preaching requires extensive preparation. An 'artful' sermon should not be an 'empty' sermon.

\section{The prophetic community}

The biblical prophets did not work in isolation from the community of faith. Rickie Moore points out that the prophet was not a lonely and isolated figure who had little to no contact with society (Moore 2007:156). Moore finds evidence from the biblical portrayals of Moses, Elijah, and Isaiah that the prophets were surrounded by colleagues and followers who supported the prophetic ministry and who participated in carrying on the prophetic tradition. In light of the biblical tradition, Walter Brueggemann connects prophecy to the overall ministry of the Church. He concludes that all acts of ministry (not just preaching) should be 'seen as elements of the one prophetic ministry of formation and reformation of alternative community' (Brueggemann 1978:14).

\section{The Pentecostal church should be a prophetic community}

The Pentecostal tradition, as Roger Stronstad (2010) has shown, claims a broad vision of prophetic speech that conceives of the Church as a community of prophets (cf. Waddell 2006:34-36). Moses had wished that all of God's people would be prophets (Nm 11:29), and Joel had promised that the prophetic Spirit would rest upon sons and daughters, old and young, and even upon servants (J1 2:28 [3:1]). The gospel narrative portrays Jesus as the prophet par excellence, who then calls his Church to be a prophetic community. For Pentecostalism, prophecy emerges not from individuals but from within the body of Christ. Therefore, the prophetic preacher is only one prophet among many.

\section{The Pentecostal church should be a discerning community}

Whenever a person claims to speak on behalf of God, that claim must be subject to a process of discernment. Therefore, prophetic preaching always invites prayerful scrutiny. John the Elder advises the following: 'Beloved, do not believe every spirit, but test the spirits to see whether they belong to God, because many false prophets have gone out into the world' (1 Jn 4:1). The apostle Paul instructs the Corinthian church to let two or three prophets speak, and let the other prophets respond with discernment (1 Cor 14:29). Gerald Sheppard suggests that this 'discernment invited by public prophecy hopefully checks the dangers of foolishness, manipulation, and even demonic voices which masquerade as true prophecy' (Sheppard 2001:64). The discerning community acts as a guard against the abuses that are mentioned above in relation to the preachers who claim special authority on account of their unique callings or divine revelations.

The process of discernment, however, is not always easy. Rickie Moore looks at discernment through the lens of Jeremiah's conflict with other prophets, especially as found in Jeremiah 28. Moore concludes that those who are under divine judgement will often be unable to discern truth from error (Moore 2011:86-100). Moreover, we should be reminded that the Old Testament prophets were seldom believed by their hearers and that Jesus Christ himself was rejected and crucified. The prophetic preacher must be prepared to accept the negative responses and criticisms that will be generated by a prophetic message.

\section{Conclusion}

Prophetic preaching is a challenging and often dangerous task. The prophetic message is not always welcomed by the 
Church. Brueggemann argues that today's preaching context includes both 'a tacit yearning in the church for the prophetic' and a 'practical reluctance or resistance' to prophetic preaching (Brueggemann 2012:130-31). Heschel (1962) observes:

It is embarrassing to be a prophet. There are so many pretenders, predicting peace and prosperity, offering cheerful words, adding strength to self-reliance, while the prophet predicts disaster, pestilence, agony, and destruction. (p. 17)

The prophetic preacher, therefore, must continually discern the tension between the dominant narrative, which is taken for granted by most people, and the Bible's alternative narrative, with the understanding that both the preacher and the church may have deep commitments and vested interests in the dominant narrative (Goldingay 2001:36-39).

\section{Acknowledgements Competing interests}

The author declares that he has no financial or personal relationships which may have inappropriately influenced him in writing this article.

\section{References}

Ahn, Y.J., 2001, 'Prophecy in the Pauline communities', The Spirit and Church 3(1), 71-95.

Ahn, Y.J., 2013, Interpretation of tongues and prophecy in 1 Corinthians, pp. 12-14, Deo, Blandford Forum.

Bishop, D.S., 1983, 'A competent workman', in R.E. Fisher (ed.), Pressing toward the mark, pp. 27-59. Pathway Press, Cleveland, $\mathrm{OH}$.

Black, H., 1983, 'Clarifying the call', in R.E. Fisher (ed.), Pressing toward the mark, pp. 9-26. Pathway Press, Cleveland, $\mathrm{OH}$.

Brueggemann, W., 1978, The prophetic imagination, Fortress, Philadelphia, PA.

Brueggemann, W., 1982, The creative word: Canon as a model for biblical education, Fortress, Philadelphia, PA.

Brueggemann, W., 1986, Hopeful imagination: Prophetic voices in exile, Fortress, Philadelphia, PA.

Brueggemann, W., 2012, The practice of prophetic imagination: Preaching an emancipatory word, Fortress, Philadelphia, PA.

Chan, S., 2000, Pentecostal theology and the Christian spiritual tradition, Sheffield Academic, Sheffield. Dayton, D.W., 1987, The theological roots of Pentecostalism, Scarecrow Press,
Metuchen, NJ.
Dodson, J.D., 2011, 'Gifted for change: The evolving vision for tongues, prophecy, and other charisms in American Pentecostal Churches', Studies in World Christianity 17, 50-71.

Faupel, W., 1996, The everlasting gospel: The significance of eschatology in the development of Pentecostal thought, Sheffield Academic Press, Sheffield.

Fee, G.D., 1994, God's empowering presence: The Holy Spirit in the letters of Paul, Hendrickson, Peabody, MA.

Goldingay, J., 2001, 'Old Testament prophecy today', The Spirit \& Church 3(1), 27-46. Heschel, A.J., 1962, The Prophets (I and II), Harper \& Row, New York.

Hvidt, N.C., 2007, Christian prophecy: The post-biblical tradition, Oxford, New York.

Land, S.J., 2010, Pentecostal spirituality: A passion for the Kingdom, CPT Press, Cleveland, $\mathrm{OH}$.

LaRue, C.J., 2011, I believe I'll testify: The art of African American preaching, Westminster John Knox Press, Louisville, KY.

Leoh, V., 2006, 'A Pentecostal preacher as an empowered witness', Asian Journal of Pentecostal Studies 9(1), 35-58.

Lum, D., 2010, 'Christian prophecy: The post-biblical tradition', Journal of the European Pentecostal Theological Association 30(1), 113-114.

Maimela, S.S., 1990, The emergence of the Church's Prophetic Ministry: An essay on modern trends in theology, Skotaville Publishers, Braamfontein, Johannesburg.

McQueen, L.R., 2009, Joel and the spirit: The cry of a prophetic hermeneutic, CPT Press, Cleveland, $\mathrm{OH}$.

Medicus, F., 1917, Grundfragen der Ästhetik: Vorträge und Abhandlungen, Diederichs, Jena.

Melton, N.J., 2011, 'Lessons of lament: Reflections on the correspondence between the Lament Psalms and early Australian Pentecostal Prayer', Journal of Pentecostal Theology 20(1), 68-80.

Milavec, A., 2004, The Didache: Text, translation, analysis, and commentary, Liturgical Press, Collegeville, PA.

Moore, R.D., 2004, 'The prophetic calling: An Old Testament profile and its relevance for today', Journal of the European Pentecostal Theological Association 24, 16-29.

Moore, R.D., 2007, 'The prophet as mentor: A crucial facet of the biblical presentations of Moses, Elijah, and Isaiah', Journal of Pentecostal Theology 15(2), 155-173.

Moore, R.D., 2011, The spirit of the Old Testament, Deo, Blandford Forum.

Nelson, C.A., 1914, 'From Sin to My Pentecost', Church of God Evangel 5(39), 6-7.

Preacher, N., 2015, Oxford English Dictionary Online, Oxford University Press, Oxford, UK.

Quayesi-Amakye, J., 2011, 'Prosperity and prophecy in African Pentecostalism', Journal of Pentecostal Theology 20(2), 291-305.

Robeck, C.M., 1992, Prophecy in Carthage: Perpetua, Tertullian, and Cyprian, Pilgrim, Cleveland, $\mathrm{OH}$.

Sandford, R.L., 2009, The Prophetic Church: Wielding the power to change the World, Chosen Books, Grand Rapids, MI. Sheppard, G.T., 2001, 'Prophecy: From ancient Israel to Pentecostals at the end of the
modern age', The Spirit \& Church 3(1), 47-70.

Stronstad, R., 2010, The prophethood of all believers: A study in Luke's charismatic theology, CPT Press, Cleveland, OH.

Tomlinson, A.J., 2012, The diary of A.J. Tomlinson: 1901-1924, White Wing, Cleveland, OH. Waddell, R., 2006, The spirit of the book of revelation, Deo, Blandford Forum.

Wesley, J., 1909, The journal of the Rev. John Wesley, 8 vols., Culley \& Kelley, London. Wriston, W., 2015, 'Tithing (Mal. 3.8-12)', Chapel Sermon, Pentecostal Theological Seminary, Cleveland, TN, viewed n.d., from https://vimeo.com/124343450 